\title{
Manfred Sommer
}

\section{Beskrivelse af mennesket - interview med Manfred Sommer}

Prof. Dr. Manfred Sommer er ansat ved Christian-Albrechts-Universität zu Kiel. Ud over forskningsmæssige interesser i fænomenologien, der fx har resulteret i værket Sammeln. Ein philosophischer Versuch (Suhrkamp, 2002), er Prof. Sommer redaktør og udgiver af Hans Blumenbergs efterladte og upublicerede skrifter i samarbejde med Blumenberg-arkivet ved Deutsche Nationalarchiv i Marbach. Dette har foreløbigt resulteret i adskillige udgivelser og senest værket Beschreibung des Menschen (Suhrkamp, 2006). Dette interview fandt sted i november 2005 ved det filosofiske seminar i Kiel.

Frank Beck Lasssen: Hans Blumenberg var et menneske med mange interesser og er ikke nem at kategorisere. Han er blevet kendt som litterat, videnskabshistoriker, som idéhistoriker og som filosof. Hvad ville De foretrakke?

Manfred Sommer: Jeg ville foretrække filosof. Jeg ville i hvert fald først og fremmest betegne ham som filosof, for selv når han vender sig mod litteraturen, mod videnskaben eller videnskabshistorien, gør han det altid i et filosofisk perspektiv og aldrig ud fra en - og dette sagt i ordets neutrale forstand - positivistisk tilgang, ud fra hvilken man sagtens kan bedrive meningsfuld videnskabshistorie. Blumenbergs tilgang til disse emner er altid filosoffens. Selv når han vender sig mod litteraturen, er det snarere fordi denne bruges til at skabe impulser, til bekræftelse, opmuntring og ansporing af ting, som er vigtige for filosoffen Blumenberg.

Så meget for Blumenbergs titel. I dag, ti år efter Blumenbergs dod, har vi så også fået en smule distance til hans arbejde. Hvorledes ville De beskrive hans nuvarende stilling $i$ det intellektuelle liv $i$ Tyskland? 
Det er ikke nogen enkel sag at gøre, for den tyske filosofi er lige for tiden stærkt præget af den angelsaksiske filosofi, af analytisk filosofi. Dette betyder, at den hermeneutiske filosofi, og også den fænomenologiske filosofi, som Blumenberg er tættere forbundet med, ikke længere befinder sig i centrum af det filosofiske liv i Tyskland. Fænomenologisk filosofi er dog stadig væk kraftfuld og der findes også - og dette hænger sammen med den amerikanske måde at filosofere på - nye forbindelser mellem analytisk filosofi og fænomenologi, som knytter sig til begrebet intentionalitet. I USA har der siden 1970'erne eksisteret tætte forbindelser mellem analytisk filosofi og fænomenologi og her kan Blumenbergs filosofi, såfremt den præsenteres fænomenologisk, finde en række forbindelsespunkter, således at man kan forvente, at Blumenbergs filosofi vil kunne opnå en større opmærksomhed, end det er tilfældet lige nu. Ved siden af dette er der en ret så stor opmærksomhed blandt åndsvidenskaberne og måske særligt i litteraturvidenskaben. Måske fordi åndsvidenskaberne ikke rigtigt ved, hvad de skal stille op med den analytiske form for filosofi.

Men hvad så med de historiske varker - Die Legitimität der Neuzeit, Die Genesis der kopernikanischen Welt - hvad sker der med disse varker? Glider de lige så stille $u d$ ?

Die Legitimität der Neuzeit er vel, selvom det måske nok er det mest kendte værk, eller i det mindste det værk, som Blumenberg har gjort kendt, på mange måder et tidsbundet værk, men samtidig også et af de sidste af Blumenbergs værker, der havde denne stærke tidslige forankring. Spørgsmålet der behandles lyder noget i stil med: Det modernes afslutning eller fortsættelsen af det moderne, noget man diskuterede heftigt i 1950'erne. I dag er det nok ikke helt så vigtigt et tema, selvom spørgsmålet om det postmoderne og modernitetens afslutning nok en gang har intensiveret debatten. Det er egentlig en skam, fordi en af Blumenbergs centrale pointer netop består i diskussionen af den senmiddelalderlige nominalisme, noget som bliver særdeles anskueligt fremstillet $\mathrm{i}$ afsnittet om "Sekularisering og selvhævdelse".

Det stiller sig lidt anderledes med hvad jeg selv anser for at være Blumenbergs hovedværk, nemlig Die Genesis der kopernikanischen Welt, som Blumenberg for øvrigt også selv regnede for sit vigtigste værk. Efter at Arbeit am Mythos havde vakt en del opmærksomhed, sagde Blumenberg engang med en vis resignation - og jeg citerer her nærmest ordret: "Ja, sådan noget som Arbeit am Mythos, det skriver jeg jo mere ved siden af. Det rigtige arbejde ligger gemt i en bog som Die Genesis der kopernikanischen Welt' - og det mærker man også, ikke sandt? Arbeit am Mythos, hmm ... det er refleksioner hos en mand, der har beskæftiget sig med Goethe, med forholdet mellem leg og terror, med distan- 
ceringer og så videre. Det har dog mere en lethed og et strejf af det geniale over sig, hvorimod Die Genesis der kopernikanischen Welt simpelthen har store mængder filologisk og historisk forskning gemt i sig. Her kan man roligt sige, at der er investeret årtiers arbejde. Derfor regnede Blumenberg dette værk for et vigtigere værk. Måske ikke for det vigtigste, men for et vigtigere værk.

Der er så det ejendommelige ved receptionen af dette værk, som jo længe har forelagt i engelsk oversættelse, at videnskabshistorikerne egentlig ikke er så glade for denne bog, fordi det trods alt er et filosofisk værk. Det er et filosofisk værk, som stiller spørgsmålet: Hvorledes forandrer bevidsthedsstrukturer sig i takt med videnskabshistorien, hvorledes forandrer vores verden som helhed sig igennem videnskabshistorien, og omvendt, hvad er implikationerne af en sådan forandring i verdensbilledet for den måde, hvorpå der bedrives videnskab? Dette er en problemstilling, som er relativt fremmed for den traditionelle og klassiske videnskabshistorie. Et sådant større anlagt studie er ikke et hovedtema for den, og derfor er Die Genesis der kopernikanischen Welt ... tja, en bog som så mange af Blumenbergs: Spændende og interessant, men for de rigtige specialister - om der så er tale om fagfilosoffer eller videnskabshistorikere - er det ikke rigtigt noget, der tæller med til faget.

Det er måske på grund af den hermeneutiske dimension $i$ Blumenbergs arbejder. Alle undersogelser drejer sig om 'meningsfuldhed', noget, der narmest forekommer at vare et filosofisk udgangspunkt for Blumenberg?

Ja, eller hvad Blumenberg ind imellem kalder ,fra mening til betydning og betydningsfuldhed“" (von Sinn zu Bedeutung und Bedeutsamkeit). Betydningsfuldhed skal gennemgående forstås i sammenhæng med betydningen af mening på den ene side og af vigtighed på den anden. Det betydningsfulde rummer begge disse sider. Meningsfuldhed betyder 'og vigtighed'. Dette er indeholdt i begrebet om betydningsfuldhed. Et begreb, som ikke kun er af betydning, når Blumenberg anvender det. Også når han ikke anvender det, er det af stor betydning for hans måde at bedrive filosofi, filosofihistorie, metaforhistorie og videnskabshistorie på. For så vidt hører disse overvejelser strengt taget også ind under filosofien, men den har det med sin stærke analytiske udrustning som sagt svært med dette. Den nyere, den nyeste, analytiske filosofi ser da efterhånden også ud til at sige: "Skal vi altid beskæftige os med disse småtterier? Det er selvfølgelig vigtigt, og man skal også kunne det og så videre, men... hmm... vi ville vel egentligt noget mere." At man er på vej til at genopdage dette i den analytiske filosofi kunne måske tale for, at man også er i stand til at genopdage betydningen af Blumenbergs filosofi. 


\section{En salsomt svavende filosofi}

Det er blevet sagt, at vi ved meget gennem Hans Blumenberg, men at vi ikeke ved meget om bam. Det forekommer, at det nasten er blevet almindeligt at anse ham for at vare en form for outsider, både professionelt og personligt. Hvorledes ser De på dette billede, der er blevet skabt? Har det noget på sig?

Det er rigtigt nok, at han ikke ville vise sig selv. Han ønskede ikke at træde frem. Man kan måske sige: Ikke selv at træde frem, men at lade noget fremtræde - nemlig bøgerne! Ikke selv optræde offentligt, men i stedet publicere. Grundintentionen bag er: Hvad jeg ønsker at vise af mig selv, det står her, det kan I læse og andet får I ikke at se.

Det er lidt noget andet med spørgsmålet om deltagelsen i det professionelle liv, filosofien har jo også en organisationsform, som vi her kan kalde det tyske forskningsfællesskab. Her gælder det, at Blumenberg ind til det afgørende år 1986 var yderst engageret $i$ videnskabernes organisering. Han var medlem af senatet for det tyske forskningsfællesskab, kløede på med grundlæggelsen af filosofi ved universitetet i Gießen, deltog i forskningsgruppen Poetik und Hermeneutik - og en række lignende aktiviteter, hvor han, i det mindste inden for filosofiens områder, fik markeret et "Ja, jeg er her, jeg er klar til at engagere mig i, hvad der skal til for at holde filosofien som akademisk disciplin i live." Dette fik dog en ende omkring 1986, hvor han trak sit engagement tilbage. Formodentlig fordi han - med god grund - ikke var interesseret $i$ at lade sig slide op af de kampe, der dengang var under opsejling. Der var andre, mere stridslystne figurer, som fx Herman Lübbe, der også anså 1986 for at udgøre en cæsur og som sagde: "Så må man stå imod, så må man gøre noget, man må..." ja, hvad...? over for en sådan indstilling sagde Blumenberg: "Nej. Så trækker jeg mig tilbage. Jeg vil ikke have mere med det at gøre. Fra nu af forfølger jeg kun mine egne forskningsaktiviteter."

For at bidrage til mystikken er det også blevet påpeget, at hans arbejder udgor 'en salsomt svavende filosofi uden endelige modtagere'- og Blumenberg har da beller ikee dannet skole eller efterladt sig mange elever. Er det overhovedet muligt at tale om nogen blumenbergsk virkningshistorie?

Lad mig starte et andet sted. Filosoffer arbejder gerne med en tese eller med teser; helst kun en, eventuelt tre, okay - men allerhøjest fem! Det ligger så at sige i den retoriske tradition. Her er der tale om tilspidsede teser, således at disse relativt let lader sig referere og citere. Det egner Hans Blumenbergs filosofi sig overhovedet ikke til. 
Adorno har en gang sagt: "Filosofi lader sig frem for alt ikke referere". Om dette gælder for Adornos filosofi? Ja måske - det forekommer i hvert fald at gælde for Blumenbergs filosofi, og det forekommer mig også at gælde for en forfatter, som Blumenberg satte stor pris på, nemlig Georg Simmel, om hvem man egentlig kun kan sige: Man fanger ikke noget af det, hvis man formulerer det som en tese. Meget hos Blumenberg lader sig bringe på teseform, fx udsagnet: "Det moderne menneske er først og fremmest karakteriseret ved, at det må værge sig mod en overflod af muligheder; gennem videnskab og teknik organiserer det sit liv." Godt så. Men det er jo en forholdsvis triviel tese, og Blumenbergs pointe ligger da også mere i måden, hvorpå han gennemspiller og når frem til en sådan sætning. Derfor lader de fleste af Hans Blumenbergs værker sig ikke forme efter en tese. Man må i stedet gøre sig besværet at læse dem og at lade sig føre igennem dem. Herefter mærker man også, at det interessante ved Blumenberg ikke så meget er begrundet $\mathrm{i}$ interessante teser, men i tænkningens stilistiske egenart, i denne indirekthed og lyst til omveje og overraskelser. Det er frem for alt som filosofisk forfatter han udøver en fascination.

Det er selvfølgelig også derfor, at virkningshistorie... aah, sådan fungerer det ikke rigtigt. Jeg nævnte Georg Simmel. Mange Simmel-kendere vil sige: "Simmel hører til en af det 20. århundredes mest indflydelsesrige filosoffer." Spørges der så: "Med hvilken tese da! Hvor er det, man ser ham citeret? Ja, så må man sige: "Hmm... Ja, det er ikke helt så let at se." Alligevel var mange filosoffer i sin tid fascineret af ham og lod sig inspirere af ham, men sådan at man må sige, at alt er foregået langt mere indirekte. Man citerede ham ikke, men lod sig i stedet bringe på andre tanker, opmuntre, inspirere og animere. Det var en sådan virkning, Georg Simmel havde, og denne form for virkning lader sig også iagttage hos Blumenberg. Altså, at der - selv hvor han ikke citeres, fordi man dårligt kan citere ham, da der ikke gives disse prægnante teser - finder en indflydelse sted.

Noget, der slår mig som unikt ved Hans Blumenberg, er, at hans måde at stille sporgsmål til sit materiale på kan forekomme en smule gammeldags. Og det skal forstàs som noget positivt. Det forekommer, at han har varet $i$ stand til at opretholde det meningsfulde $i$ store, narmest kosmologiske sporgsmål, for derigennem at tillade os andre at indgå $i$ dialog med tanker og idéer, der ellers mätte synes markelige og overflodige?

Ja, men snarere på den måde at han betragter gamle spørgsmål, traditionelle spørgsmål som nogle, om hvilke man må sige: Det er ikke tilfældigt, at disse engang udgjorde et tema. De må derfor have en betydning for os mennesker i al almindelighed - og det vil også sige for os, der er nulevende. Det fører så vidt, at han udvikler en svaghed for det utidssvarende og marginale, for fodnoter, 
skurriliteter og ejendommeligheder, som for størstedelens vedkommende først er begyndt at virke som ejendommeligheder i dag. Ejendommeligheder, som $\mathrm{i}$ deres egen tid havde en betydning for mennesker. Det gælder om at huske og at vise, at hvad der overhovedet ikke interesserer os i dag - vi spørger ind imellem: Hvordan kunne de finde på at beskæftige sig med sådanne ting? - langt fra var så underligt eller forblændet. Også disse spørgsmål gemmer på noget, der er interessant for mennesket og dermed for os nulevende, og deraf kommer forsøget på at aktualisere disse eller i det mindste at holde dem i live. Det mærkværdige må ikke gå tabt, bare fordi det forekommer at være mærkværdigt.

\section{Mellem fanomenologi og antropologi}

Det er af mange - forst og fremmest Odo Marquard - blevet bemarket, at der findes en grundtanke $i$ alle de historiske undersogelser: Idéen om et Animal Symbolicum, som bruger en retorisk evne til at kompensere for en generel mangel på magt over verden. I hvilket omfang er det rimeligt at sige, at en sådan grundtanke styrer undersogelserne?

Jeg tror, at Blumenberg, når det kommer til dette spørgsmål, er præget af Arnold Gehlens antropologi. Forestillingen om et overskud af stimuli og behovet for at konfrontere sig med en verden af stimuli, at bringe orden $i$ verden, at skaffe struktur på verden udgøres kun på overfladen af Arnold Gehlens antropologi. Bag en sådan 'grundtanke' står også Blumenbergs analyse af nominalismens vilkårlige Gud og den dermed forbundne overflod af muligheder, der gør, at mennesket ikke længere føler sig hjemme i verden og derfor må se sig tvunget til på anden vis at gøre verden hjemlig. Noget der frem for alt finder sted gennem teknikken. Denne lokalisering af en menneskelige situation i senmiddelalderen er på én og samme tid en antropologisk tese hos Blumenberg. Det er ikke sådan, at man kan sige: "I den sene middelalder og det tidligt moderne er netop denne situation opstået." Det er snarere sådan, at den antropologiske ursituation her opnår en særlig tydelig udformning. Søger man svar på spørgsmålet: Hvorledes stiller det sig med mennesket? Så lader det sig finde med en særlig tydelighed i den sene middelalder og det tidligt moderne, hvor der finder en konfrontation sted med nominalismens voluntaristiske Gud. Dette er ikke blot en historisk tese, men også en antropologisk tese.

Nu pegede De selv på, at forestillingen om et symbolsk dyrs kompensationer forer os $i$ narbeden af den filosofiske antropologi. Fra et dansk synspunkt forekommer denne at vare en unike filosofisk position $i$ Tyskland med vigtige navne sassom Max Scheler, Helmuth Plessner og Arnold Geblen. Hvad var Blumenbergs forbold til denne gruppe af tankere? De navnes ikke så ofte, som man skulle tro i hans varker. 
Nej, men i forelæsningerne. I forelæsningerne over antropologi henviste Blumenberg udførligt til Plessner, til Scheler og til Gehlen, så man mærkede, hvorledes hele den tyske antropologitradition i allerhøjeste grad optog ham. Han kendte dem godt, og særligt Arnold Gehlen, som jeg allerede har nævnt, var hele tiden en tænker, med hvem han følte en vis affinitet. Egentlig også med Nicklas Luhmann, som nok snarere har ladet sig inspirere af Blumenberg end omvendt. Man kan måske sige, at Arnold Gehlen med sin antropologi har været en fælles fader for de to.

Men det er jo ikeke gjort med antropologien. Man kunne måske sige, at Blumenbergs antropologi er under indflydelse af fanomenologien. Sarligt Husserl har varet en fast samtalepartner gennem hele karrieren. Hvor har dette forhold til fanomenologien drevet ham hen?

Først og fremmest må man gå ud fra, at Blumenberg ville være begge ting: Antropolog, altså en filosof der beskæftiger sig med mennesket, og fænomenolog, altså en filosof, der beskæftiger sig med bevidsthed - og her taler vi frem for alt om bevidsthedens forbindelser til verden. Bevidsthed er verdensforbindelse og ikke noget aflukket for sig. Så kan man slå genvej og sige: "Nå ja, det hænger jo sammen: Mennesket er et bevidsthedsvæsen, og derfor ligger en fænomenologisk antropologi lige for." Men Blumenberg tager her helt anderledes fat og er langt mere tro mod Edmund Husserls traditionslinje. Han siger nemlig: Fænomenologi er ikke en teori om den menneskelige bevidsthed, men en teori om bevidsthed overhovedet. Derfor holdt Blumenberg lange forelæsninger over temaet: "Muligheden af en fænomenologisk antropologi". Muligheden af en fænomenologisk antropologi, fordi udtrykket 'fænomenologisk antropologi' for ham at se udtrykker en contradictio in adjecto. På den ene side handler jeg ud fra en bevidsthed overhovedet, på den anden side handler jeg som et sådan og således beskaffent væsen med øjne, ører, hænder og med ernæringsmæssige og seksuelle behov. Det har på det nærmeste intet med bevidsthed at gøre. Derfor knytter Blumenberg an ved Husserls sene, spekulative overvejelser over den transcendentale bevidstheds selvlegemliggørelse og selvverdensliggørelse. Husserl har en forestilling om, at bevidsthed overhovedet er af en sådan karakter, at den ikke kan finde andet udtryk end som legemlig bevidsthed. Legemlighed er ikke ubetinget lig med menneskelig legemlighed, men indebærer blot, at legemet må være et sanseorgan og at det må forekomme i verden.

Der er således stadig en lille forskel mellem en legemliggjort bevidsthed og en menneskelig bevidsthed. Dette er et af de punkter, hvor Blumenberg forsøger at slå bro mellem fænomenologien og antropologien, og som man kunne tro var overflødig, hvis man ikke ser nærmere efter. Men det er nød- 
vendigt, for Husserl ønsker - aldeles i modsætning til Heidegger - en teori om bevidstheden overhovedet. Og det må man forstå: At Blumenbergs tætte forbindelse til Husserls bevidsthedsteori udgør en modposition til Heideggers eksistentialanalytik, og at den fænomenologiske antropologi, der skal komme ud af det, er ment som en modfilosofi til Heidegger. Ellers kunne man jo sige: "Ja, vil man have en fænomenologisk antropologi... Heidegger! Sein und Zeit! Findes der noget bedre!" Dertil vil Blumenberg sige: 'Ja! Det gør der - og den må se ganske anderledes ud end Heideggers filosofi."

Det forekommer, at disse to aspekter - antropologi og fanomenologi - er til stede på forskellige måder $i$ Blumenbergs undersogelser. Tager man Die Legitimität der Neuzeit, så er det en bog med en antropologisk intention. Den taler om menneskets generelle behov for kompensationer, ikke blot $i$ en sarlig periode, men $i$ almindelighed. Samtidig bavder den at ville tale om forandringerne mellem forskellige perioder, ja endda om forskellige epokers inkommensurabilitet - altså en yderst historisk, tilgang kaldet en 'bistorisk. fanomenologi'. Balancen mellem disse to perspektiver kan nasten se ud til at falde sammen. Taler vi stadigvak om det samme? Det samme forsog på at kombinere to tilgange?

Ja, det hænger tæt sammen. Der findes - i den tyske filosofi i hvert fald - en konflikt mellem antropologi og historiefilosofi, der også hører hjemme i 1960- og 70'erne. Antropologi er konservativ. Antropologi går ud fra, at verden er fast og uforanderlig. Historiefilosofi viser derimod, hvorledes alt forandrer sig og er samfundsmæssigt formidlet. Marx kunne fx lyde: Mennesket er formet af samfundsmæssige forhold, og da disse altid ændrer sig, er mennesket også altid noget andet, end antropologerne vil have det, når de fx siger: Mennesket står fast, er en fast størrelse med den og den udrustning. Endnu en gang har Blumenberg fundet en interessant måde at føre disse to sammen: Mennesket er henvist til, eller det er for mennesket væsentligt, at have et billede af sig selv. Gennem dette billede, det har af sig selv, er mennesket også foranderligt. Derfor er det at skrive de menneskelige verdensforholds historie - og dertil hører videnskabshistorien, men også metaforhistorie - selv en form for antropologi. Ikke en, hvor man kan sige: "Disse billeder er bare overfladefænomener", men en antropologi hvor spørgsmålet om, hvad mennesket er, først bliver klart for det i løbet af dets historie. I refleksionen over denne histories forløb skaffer mennesket sig klarhed over, hvad det selv er og hvordan det stiller sig med dette menneske.

Hvis vi lige skal blive lidt ved Die Legitimität der Neuzeit - og det er uden tvivl den mest kendte af Blumenbergs boger i Danmark - sä skrev han denne bog som et forsvar for den moderne verdens legitimitet, som et forsvar for en menneskelig selvbavdelse i solidaritet 
med en rakke oplysningsfilosofiske temaer. Ville det vare rimeligt at beskrive Blumenberg som en oplysningsfilosof? Jeg ved godt, at det kan ligne et underligt sporgsmål, for det er på en måde ikke rigtigt egnet til Blumenberg...

Ja, ja, men jeg forstår nu godt hvad De mener. Førhen talte vi om spørgsmålet: Lader Blumenbergs filosofi sig bringe på teseform? Formulerer man så tesen: Blumenberg er en oplysningsfilosof, og jeg var tvunget til at svare ja eller nej, så ville jeg sige ja. Men igen ser De ved denne indstilling, hvor indirekte Blumenbergs forhold er til oplysningstraditionen. Han satte dog altid oplysningstraditionens nøglebegreber - fornuft, rationalitet, gennemskuelighed, efterprøvelighed, saglighed - ganske højt og var særligt imod, at sproget hos en række franske filosoffer - fx Derrida og vel også Lyotard og Deleuze - indimellem blev en smule overgearet. Heroverfor insisterede han altid på et vist mål af nøgternhed og saglighed.

Det er vel også med baggrund i dette, at vi ser et andet forhold til begrebet 'teknik'. Det forekommer, at begrebet 'teknik' hos Blumenberg ikke bare betyder noget $i$ stil med 'apparat' eller andre lignende kritiske indvendinger. Der peges snarer på en generel kunstfardighed $i$ menneskets goren og laden.

Ja, for Blumenberg er mennesket også et teknisk væsen, og Blumenberg hører til blandt de, der aldrig har ladet sig forlede til teknikfjendtlighed eller teknikkritik. For Blumenberg var det altid vigtigt at se teknikken i sammenhæng med det antikke begreb om techné, som begge størrelser - teknik og kunst - jo stammer fra. Teknik og kunst er begge måder at konfrontere verden på, at forme verden på og dermed også måder for mennesket at forme sig selv på. Den fælles baggrund for disse fandt Blumenberg i det gamle begreb om techné, eller det middelalderlige ars, hvor man endnu ikke kendte til modsætningen mellem autonom kunst på den ene side og apparaternes teknik på den anden.

\section{Den billedlige tale}

På verdensplan må Blumenberg vel siges at vare bedst kendt for den energi, han brugte på metaforer. Men af alle menneskets kunstfardige måder at pleje omgang med verden på, bvorfor så lige metaforen?

Tja ... jeg er ikke sikker på, at der gives et helt fornuftigt svar. Et forsøg ville være at gribe tilbage til begyndelsen af "Paradigmen zu einer Metaphorologie", hvor idealbilledet af filosofi fremstilles, nemlig som en disciplin der, som Descartes forestillede sig det, må holde sig til en streng begrebslighed. Over 
for dette cartesianske rationalitetsideal fremhæver Blumenberg Kant. I forbindelse med Kants teori om symbolet - hvad der for Kant indbefatter metaforen - og Kants teori om ideen, forsøger Blumenberg at udkaste sin teori om metaforen. Og jeg tror, det hænger sammen med, at når filosofien vil tematisere sådan noget som menneskets samlede verdensforhold, må der uvægerligt komme metaforer på banen. Det er, hvad der er indeholdt i Blumenbergs begreb om absolutte metaforer. Der gives altså metaforer, som ikke lader sig afløse af begreber, og som ikke besidder en foreløbighed, om hvilken man kan sige: "Nå ja, når blot vi får de nøjagtige begreber, så behøver vi ikke den billedlige tale længere." Langt snarere er det sådan, at der findes begreber - Kant kalder dem for idéer - som kun kan vinde en anskuelighed som metaforer.

Dette er således også et anti-positivistisk forehavende. Blumenberg forstod nu at sætte pris på en vis positivisme; han var altså ikke en modstander af positivismen, men nok en modstander af meningsloshedsmistanken (Sinnlosigkeitsverdacht). Indleder man en sætning med: "Verden er ..." - så behøver man overhovedet ikke at fortsætte, så vinker positivisten af og siger: "Hvad der kommer herefter, det kan kun være det rene nonsens!" Hertil ville Blumenberg sige: "Det kan godt være, men jeg ville nu gerne kunne sige, at verden eksempelvis er en bro; eller at verden er en flod; eller et telt - og alt efter, hvad jeg nu siger, siger jeg noget forskelligt om verden i det hele taget, noget, som frem for alt er meningsfuldt eller af betydning." Og det gælder også, når sproganalytikeren vil sige: "Næh, det er aldeles meningsløse sætninger." Det tror jeg er et af de motiver, der har ført Blumenberg frem til metaforologien.

Man fär let det indtryk, at der eksisterer en form for konkurrence mellem projektet om en Historische Wörterbuch der Philosophie, sådan som denne blev konciperet af Joachim Ritter, og så det metaforologiske projekt, som Blumenberg har foreslået, eller i det mindste foreslog i 1960'erne. Det endte med, at metaforer ikke fik nogen plads $i$ Historische Wörterbuch der Philosophie, og det var noget Blumenberg udtrykte forståelse for, eftersom det ville sprange projektet - både praktisk og filosofisk. Men bvori bestair denne 'Auseinandersetzung' med begreber? Det er ikke blot en strid med aldre figurer såsom Descartes, det er også noget, der var pågående...

Ja, det er også en strid med Hegel. Man må se det her i en tæt sammenhæng med begge navnene Joachim Ritter og Hegel. Ritter var gennemført hegelianer, og en begrebshistorisk ordbog er i bund og grund et hegeliansk projekt: "Begrebets vej til idéen gennem virkeligheden", eller noget i den stil. Dette må kunne forfølges filosofihistorisk, idet man forfølger, hvorledes begreberne forvandler sig. Derfor spiller Ritter, og Gadamer, der i den her sammenhæng også tæller som hegelianer, en væsentlig hovedrolle for dette projekt; en histo- 
risk ordbog over filosofien, der frem for alt er en begrebshistorie. Her forekom det Blumenberg, at ting der er ganske væsentlige for filosofien - og når vi nu tidligere har talt om idé, verden og meningsfulde udsagn, forstår man, hvorfor Blumenberg måtte få den mistanke - ikke får lov at komme til orde i et sådant koncept, i en historisk ordbog over filosofien som en begrebshistorisk ordbog. Man må så også rose de ansvarlige for gennemførelsen af denne ordbog for, at de ikke helt har ladt den metaforiske dimension ude af betragtning. Oven i dette bliver der her i Kiel, af Ralf Konersmann, udarbejdet en ordbog over filosofiske metaforer, der så at sige kan tjene som et supplement eller en udvidelse af projektet om en historisk ordbog for filosofien.

Denne seneste udvikling er interessant. Jeg sporger, fordi "Paradigmen zu einer Metaphorologie" blev udgivet 1960 med en lang rakke markeringer, som indikerede begyndelsen til en ny disciplin, eller i bvert fald en ny forskningsretning, men det blev ligesom aldrig til mere end det, og senere varker, såsom Die Lesbarkeit der Welt, har tabt den programmatiske karakter, som det tidligere vark havde. Opgav Blumenberg det metaforologiske projekt?

Der er tale om to forskellige ting. En filosofisk teori om metaforen. Det er det ene. Og så fremstillinger, særligt filosofihistoriske fremstillinger, af metaforer, sådan som disse forandrer sig med tiden. Det er det andet. Da vi talte om spørgsmålet: "Lader Blumenbergs filosofi sig bringe på teseform?", var vi ganske tæt på en af grundene til, at Blumenberg aldrig forfulgte en teori om metaforen med nogen større alvor, og hvorfor han omvendt forfulgte metaforhistorien med større iver. Her tænker jeg fx på Schiffbruch mit Zuschaner, Die Lesbarkeit der Welt, Höblenausgänge og Das Lachen der Thrakerin. Altså studier af enkeltmetaforer - "Beobachtungen an Metaphern", kaldte han et mindre arbejde. Disse var vigtigere for ham end en teori om metaforen. Ser man på "Paradigmen zu einer Metaphorologie", så betyder det, hvis man tager titlen alvorligt, og det mener jeg, at man må, noget i stil med: Metaforologien er ikke bare en teori om metaforen, men er fremstillingen af metaforer i deres kontekst, deres historiske udviklinger og deres funktioner i de forskellige discipliner. Alligevel savner man også en teori om metaforer en smule. Der findes de her små tekster i indledningen til "Paradigmen zu einer Metaphorologie" og senere nogle løse sider om en teori om ubegrebslighed, men det er ikke noget tilfælde, at det kun drejer sig om få sider. Blumenbergs teori om metaforer er vel alt $\mathrm{i}$ alt på en tyve sider. Metaforologien i dens materielle, historiske og righoldige betydning omfatter derimod hundredvis af sider. Her var der noget på færde, mente Blumenberg, og ikke så meget i spørgsmålet "Hvorfor bruger mennesket metaforer?’ Så hellere gennemgå de metaforer der rent faktisk bruges for at finde et svar på dette spørgsmål. 
Angående metaforer, så synes de at besidde et privilegeret forbold til, bvad jeg forhen beskrev som Blumenbergs 'bedagede' sporgsmål. Metaforologien - altså netop interessen for metaforens kontekst, for dens forskellige historiske veje og omveje frem for en filosofi om metaforen - peger for mig at se i den samme retning, mod en interesse i de ting, der nasten er glemte. Der synes at vare et falles fodslag her, men det stär ikke helt tydeligt for mig hvorledes...

Jo, jo, men det er jo interessen for det undertrykte, det åbenlyst marginale, det overhalede og forældede. Blumenberg har det skønne udtryk "samtidens absolutisme", som peger på den tilbøjelighed, vi har til at gøre, hvad vi i dag finder rigtigt, relevant og formålstjenligt til målestokken for et blik tilbage i tiden. Et blik, som kan sortere imellem, hvad der er vigtigt og ligegyldigt. Men hvad vi ud fra 'samtidens absolutisme' gerne betragter som overflødigt, som noget vi roligt kan glemme, er vigtigt for Blumenberg. Over for en sådan absolutisme råber Blumenberg: "Stop! Intet må glemmes." Alt, hvad der er tænkt, selv det mærkeligste og det forkerte, er af betydning for vi menneskers selvforståelse. Forbilledet er her Kants transcendentale dialektik, hvor Kant siger: "Altså ved I hvad? Selv den værste dogmatisme er dog en betragtning værd, for fejlene gjort der er ikke fejl, hvorom man kan sige: "Det ville have været bedre, at de aldrig var lavet." Nej, det var godt, at de blev lavet, for uden disse fejl var vi aldrig kommet nærmere sandheden."

\section{De efterladte skrifter}

Forskelligt materiale fra de efterladte skrifter - som opbevares ved Deutsches Litteraturarchiv i Marbach - bliver nu udgivet med Dem som redaktor. Kan De give os en beskrivelse af indholdet $i$ de efterladte skrifter?

Ja, det rummer frem for alt mange fænomenologiske arbejder. Her tænker jeg særligt på arbejdet med en fænomenologisk antropologi, men der findes også noget om eskatologiske filosofier, altså om spørgsmålet: Hvilke tanker har filosofferne egentlig gjort sig om verdens ende? Som altid hos Blumenberg er emnet indirekte behandlet, det er ikke sådan, at han selv fremstiller en eskatologi. I stedet overvejer han, hvilke former og hvilke strukturer filosofferne ser være på færde, når de beskæftiger sig med verdens ende. Der findes en del, lige fra altings endelige og katastrofale slutning til forestillingen om, at alt vil fortsætte uforandret. Sa filosofisk eskatologi findes der en del af. I mindre grad nye metaforhistorier; dér er ikke så meget mere at komme efter. Derimod findes der en del om Freud, så meget at der en gang i fremtiden vil udkomme en eller anden Freud-bog. Freud er i øvrigt også en del af den fænomenologiske antropologi. Dette forhold kendes også fra de forelæsninger han holdt, 
hvor han ind imellem næsten stønnede og - til alles overraskelse selvfølgelig - sagde: "Ind imellem kan man slet ikke skelne mellem Freud og Husserl længere." Fordi alt hos Husserl kaldes for sedimenteringer, aflejringer og habitualiseringer, kan man iagttage en overraskende lighed med, hvad Freud kalder for det ubevidste.

Ja, nu er De allerede begyndt at tage fat på afslutningen af dette interview, for jeg havde tankt mig at slutte af med at sporge, hvad vi kan forvente fra de efterladte skrifter i fremtiden?

Jamen, frem for alt så udkommer den filosofiske antropologi inden længe. Det er dog stadig usikkert, hvad den kommer til at hedde, idet Blumenberg afprøvede forskellige titler. En af de titler, han havde under overvejelse, var Beschreibung des Menschen - en enkel og flot titel, men nok også en titel der lyder en smule gammeldags. Ellers er der overordnet set udkommet de ting fra de efterladte skrifter, hvor det var tydeligt, hvilken type bog Blumenberg selv forestillede sig. Altså hvor der forelå konvolutter, som fx Goethebogen, $Z u$ den Sachen und Zurück og Die Verfübrbarkeit des Philosophen. Det er bøger, som Blumenberg allerede havde konciperet som bøger, idet teksterne var ordnede og med indholdsfortegnelse. Ganske vist var alt, hvad Blumenberg nedskrev, beregnet på offentliggørelse, men det er ikke særligt tydeligt, hvordan resten skal ordnes. Hvad der bliver den næste udgivelse, må fremtiden vise. 